\title{
Innovations in Sustainable Agriculture: Case Study of Lis Valley Irrigation District, Portugal
}

\author{
Maria de Fátima Oliveira ${ }^{1,2, * \mathbb{C}}$, Francisco Gomes da Silva ${ }^{3}$, Susana Ferreira ${ }^{1}$, \\ Margarida Teixeira ${ }^{4}$, Henrique Damásio ${ }^{5}$, António Dinis Ferreira ${ }^{1,2} \mathbb{D}$ and \\ José Manuel Gonçalves ${ }^{1}$ \\ 1 Instituto Politécnico de Coimbra, Escola Superior Agrária, 3045-601 Coimbra, Portugal; \\ susanacatarinaferreira@gmail.com (S.F.); aferreira@esac.pt (A.D.F.); jmmg@esac.pt (J.M.G.) \\ 2 CERNAS-Research Centre for Natural Resources, Environment and Society, Escola Superior Agrária de \\ Coimbra, Bencanta, 3045-601 Coimbra, Portugal \\ 3 Instituto Superior de Agronomia, Universidade de Lisboa, Tapada da Ajuda, 1349-017 Lisboa, Portugal; \\ fgsilva@isa.ulisboa.pt \\ 4 Direção Regional de Agricultura e Pescas do Centro, Rua D. José Alves Correia da Silva, 14-B, \\ 2410-117 Leiria, Portugal; margarida.teixeira@drapc.gov.pt \\ 5 Associação de Regantes e Beneficiários do Vale do Lis, Quinta do Picoto, Souto da Carpalhosa, \\ 2425-492 Leiria, Portugal; hdamasio71@gmail.com \\ * Correspondence: foliveira@esac.pt; Tel.: +351-96-575-3644
}

Received: 14 November 2018; Accepted: 4 January 2019; Published: 10 January 2019

\begin{abstract}
The innovation of agricultural systems management is a determinant factor that guarantees adaptation to a new paradigm of global economy, environmental protection, and social requirements. The conventional concepts of innovation, applicable to new products and processes, do not consider many characteristics of the agricultural sector, such as social innovation and innovation resulting from new or renewed processes. Nevertheless, the overall impact of innovation on yields, competitiveness, and value can be hampered by the limited understanding or misinterpretation of Agriculture Innovation paradigms. For instance, the Rural Development Program (RDP) applies a restrict concept of innovation, being unable to embrace the full range of activities intended to implement new practices within the framework of the Agricultural Knowledge and Innovation System (AKIS). Stimulating innovation in agriculture demands a change in policy innovation of RDP in order to preserve natural resources and combine agricultural priorities and the rural environment with the concepts of innovation. This paper focuses on the different views of the concept of innovation within the Program of Operational Groups (OGs) of the European Innovation Partnership for Agricultural Productivity and Sustainability (EIP-AGRI), analyzing the Portuguese case study of the Lis Valley Irrigation District whose main innovation objective was to achieve and implement new processes of water management aiming at the conservation of natural resources as well as sustainable social and economic agricultural development. The Portuguese experience highlights why the application of innovation in agriculture may not reach the desirable outcomes.
\end{abstract}

Keywords: innovation; operational groups; Vale do Lis; RDP; AKIS

\section{Introduction}

Innovation is a key factor that can be used to overcome the main challenges brought about by global change-namely, the constraints posed by climate change on the Mediterranean Region, which would be particularly muddled by water problems. Innovation is the only factor capable of increasing competitiveness in the agri-food sector. Innovation niches may facilitate transitions toward sustainable agriculture prospects [1]. Innovation in the agricultural sector is interlinked with 
a set of factors in which the implementation of new thinking models is implicit and represents the development of a set of technological, management, and socio-economic tools aiming at improving the living standards of society in a sustainable manner. According to the European 2020 strategy (Horizon 2020), European Union (EU) countries are encouraged to increase investments in research and development (R\&D) so that by 2020 it may represent 3\% of national Gross Domestic Product (GDP), allowing for an EU increase of around 3.7 million new jobs [2]. R\&D plays an extremely important role in productivity, competitiveness, and value, and is central to the construction of the European vision and strategies towards the future; however, the implementation of such vision and strategies in some areas may arise conceptual problems due either to their complexity or to the lack of experience in implementing innovation management systems. Agriculture is one of those fields where the complexity level is high, and in the particular case of Portugal, this is the first time that a funding program has been designed to foster innovation. For these reasons, studying the program implementation provides an opportunity for a critical discussion that may be relevant for future initiatives worldwide.

As part of the CAP (Common Agricultural Policy), innovation is expected to be encouraged in Portugal by a set of sub-programs, namely CAP Area 1A, for the particular measure 16.1 (OGs). An OG case study was analyzed, highlighting the dichotomy between the concept and practice of innovation in agriculture to pinpoint the difficulties in steering innovation in agriculture.

This paper associates innovation and the agri-food market in Portugal with the purpose of linking innovation in agriculture with research and innovation challenges. The way that innovation, over the value chain of the agri-food system, increased farmers' profitability in a more sustainable way by using resources more efficiently will also be considered. This is of paramount importance to an economy willing to be more circular [3] and that is attentive to market evolution. Innovation of the processes, particularly of complex systems, such as irrigation districts management, is not always easy to understand and includes several actors. This paper focuses on innovation characteristics, the development of a new water management process, and other factors requiring a set of measures interconnected with irrigation collective infrastructures, aligned with the European Innovation Partnership for Agricultural productivity and Sustainability (EIP-AGRI) and contributing to the European Union's strategy of research and innovation within (OG) programs.

\section{Agricultural Research and Innovation in the European Union}

The CAP 2014-2020 reform states the importance of innovation and research development in agriculture. For this purpose, the Agricultural Knowledge and Innovation System (AKIS) is being developed and adapted to the agri-food chain, integrating production to the final consumer. OGs are an example of the EU's commitment to innovation in agriculture through the creation of an instrument linking several national and international partners to develop agricultural projects, with practical application for end-users with the ultimate aim of enabling more competitive and sustainable agriculture. Innovation in the agri-food system, regardless of the type of innovation-be it technological, organizational, product, or marketing $[4,5]$ — must consider the economic and social evolution of consumption.

Innovative research alone is not the basis of the EU strategy; farmers also require access to information and knowledge produced by R\&D. Producing R\&D is not the only main goal, because innovation with no knowledge transferred to farmers does not enhance agriculture innovation. Innovation is to be fostered by various rural development measures, such as "knowledge transfer", "cooperation", and "investments in physical assets" [6]. Access to knowledge should be facilitated by agricultural policy programs integrating research centers, so that the transfer is effective and applicable to agriculture [7]. The key elements of Farmers' Support: Advisory Services (PRO-AKIS) from CAP program are linked to climate change mitigation and adaptation, environmental challenges, and economic development and training, and are integrated in AKIS. The AKIS concept was introduced in the 1960s as an Agricultural Knowledge System (AKS) related to agrarian extension. With the 
development of Information and Communication Technologies (ICTs) and through the incorporation of ICTs into the AKS, it has become AKIS. Labarthe et al. [6,8] pointed out that the purpose of AKIS is to strengthen communication and knowledge delivery services to people in the rural sector. The actors include national agricultural research organizations, agricultural universities or agriculture colleges, extension services, farmers, people engaged in farm activities, Non-Governmental Organizations (NGOs), and entrepreneurs in rural areas. Rajalahti et al. [9] defined the innovation system as a "network of organizations, enterprises, and individuals that focuses on bringing new products, new processes, and new forms of organization into the economy"; thus, it is not only a matter of creating knowledge, but also a matter of going beyond the creation of knowledge. The Agricultural Innovation System (AIS) is a response to the need for rural competitiveness so as to allow it to remain competitive in a changing economic and social environment. AIS identifies the importance of technology and highlights that innovation systems are social systems. Rajalahti et al. [9] also emphasizes placing the focus on producing new products, new processes, and new forms of organization and putting them into economic use. A major feature of this new form of AIS in relation to AKIS, which integrates classical knowledge and innovation systems such as universities and research institutes, is that the new AIS integrates a much wider range of actors, i.e., the whole network of public and private stakeholders on which innovation depends [10]. The new AIS is targeted at supporting the innovation process and aiding new agroecological innovations [6].

In addition to these systems, the fact that the National Agricultural Research Systems' (NARS) goal is technology generation and transfer must not be ignored. According to the World Bank's definition, "NARS comprises all of the entities within a country that are responsible for organizing, coordinating, or executing research that contributes explicitly to the development of its agriculture and the maintenance of its natural resource base" [11].

The definitions of AKIS, AIS, PRO-AKIS, and other research systems are not clear, and several public research systems coexist [12,13]. The AKIS system works differently in different countries [14,15]. Authors such as Dockès et al. [16] highlight that there are many disconnections between the various subsystems within AKIS, and that "these disconnections impede learning and hamper effective research and innovation. AKS/AKIS is often perceived as being unresponsive and overregulated. Competition between the AKS/AKIS actors (researchers and institutes) for funding impedes collaboration between researchers and innovators" [16]. Nowadays, all systems coexist and may be perceived as competing or rival systems.

The evolution of innovation systems has led to the appearance of PRO-AKIS, aimed at the development of an inventory of agricultural advisory services in the EU. Targeted both at knowledge flows and the dynamics between advisory service organizations and other actors operating in the agricultural knowledge system, it aims at putting together the AKIS and the Advisory services. Table 1 presents some of the main features of innovations systems.

The policy concept of innovation is itself arguable. Smits et al. [17] consider two approaches to innovation: the innovation approach, and the macro-economic approach. The latter considers innovation as an $R \& D$ process designed for commercial application. The first is more complex and focuses on the interactions among different stakeholders in the innovation process [18].

When discussing innovation, Edler and Fagerberg [19] emphasized that innovation is not first and foremost about generating new ideas, but that it is about putting ideas into practice to boost competitiveness and take action to solve problems or challenges: "[It is] this 'problem-solving' nature that potentially makes innovation a relevant force to deal with important social and economic issues that politicians care about". 
Table 1. Defining structures of the four main frameworks of innovation systems.

\begin{tabular}{|c|c|c|c|c|}
\hline Acronym & NARS & AKIS & AIS & PRO-AKIS \\
\hline Definition & $\begin{array}{c}\text { National } \\
\text { Agricultural } \\
\text { Research System }\end{array}$ & $\begin{array}{c}\text { Agricultural } \\
\text { Knowledge and } \\
\text { Innovation System }\end{array}$ & $\begin{array}{l}\text { Agricultural and } \\
\text { Innovation Systems }\end{array}$ & $\begin{array}{c}\text { Prospects for } \\
\text { Farmers' Support: } \\
\text { Advisory Services in } \\
\text { European AKIS }\end{array}$ \\
\hline Propose & $\begin{array}{l}\text { Planning capacity } \\
\text { for agricultural } \\
\text { research, } \\
\text { technology } \\
\text { development, and } \\
\text { technology transfer }\end{array}$ & $\begin{array}{l}\text { Strengthening } \\
\text { communication and } \\
\text { knowledge delivery } \\
\text { services to people in } \\
\text { the rural sector }\end{array}$ & $\begin{array}{l}\text { Produce new } \\
\text { products, new } \\
\text { processes, and new } \\
\text { forms of organization } \\
\text { into economic use }\end{array}$ & $\begin{array}{c}\text { Develop an } \\
\text { inventory of } \\
\text { agricultural advisory } \\
\text { services in the EU } \\
\text { where knowledge } \\
\text { can flow. Develop } \\
\text { the dynamics among } \\
\text { advisory services, } \\
\text { organizations, and } \\
\text { other actors of the } \\
\text { agricultural } \\
\text { knowledge system }\end{array}$ \\
\hline Actors & $\begin{array}{l}\text { National } \\
\text { agricultural } \\
\text { research } \\
\text { organizations, } \\
\text { agricultural } \\
\text { universities or } \\
\text { agriculture } \\
\text { colleges, extension } \\
\text { services, and } \\
\text { farmers }\end{array}$ & $\begin{array}{l}\text { National agricultural } \\
\text { research organizations, } \\
\text { agricultural } \\
\text { universities or } \\
\text { agriculture colleges, } \\
\text { extension services, } \\
\text { people engaged in } \\
\text { farm activities, NGOs, } \\
\text { and entrepreneurs in } \\
\text { rural areas }\end{array}$ & $\begin{array}{l}\text { Potentially all actors } \\
\text { in the public and } \\
\text { private sectors } \\
\text { involved in the } \\
\text { creation, diffusion, } \\
\text { adaptation, and use } \\
\text { of all types of } \\
\text { knowledge relevant } \\
\text { to agricultural } \\
\text { production and } \\
\text { marketing }\end{array}$ & $\begin{array}{c}\text { Set of organizations, } \\
\text { public and private. } \\
\text { Formal extension } \\
\text { services, training, } \\
\text { and post-secondary } \\
\text { education. NGOs, } \\
\text { administration } \\
\text { members, or research } \\
\text { institutions. }\end{array}$ \\
\hline $\begin{array}{l}\text { Organizing } \\
\text { Principle }\end{array}$ & $\begin{array}{l}\text { Using science to } \\
\text { create inventions }\end{array}$ & $\begin{array}{l}\text { Accessing agricultural } \\
\text { knowledge }\end{array}$ & $\begin{array}{l}\text { New uses of } \\
\text { knowledge for social } \\
\text { and economic change }\end{array}$ & $\begin{array}{l}\text { Produce advisory } \\
\text { services as an } \\
\text { intangible service } \\
\text { activity and as } \\
\text { intangible } \\
\text { investments }\end{array}$ \\
\hline
\end{tabular}

Source: Adapted from [8].

The Organisation for Economic Co-operation and Development (OECD) $[4,20,21]$ stated that innovation can take many forms: Introducing a new or significant improvement in the product, service, process, marketing or marketing method, and organizational method, both in the form of commercialization and company internal organization and/or its relations with the external world.

Gault $[22,23]$ assessed the measurement and definition of innovation in different economics sectors, using a systems approach to develop a framework for the statistical measurement of innovation. According to the Green Paper [24], innovation flows within the system, and business innovation can be grouped according to: (i) Strategic competences: long-term analysis; ability to identify and anticipate market trends; availability to gather information and process technological and economic data; (ii) Organizational capacity: taste and risk mastering; internal and external cooperation; involvement of the entire company in the process of change and investment in human resources.

\section{Material and Methods}

Evaluating innovation processes, particularly of complex systems such as irrigation districts management, is particularly difficult, especially when the various stakeholders and key actors are involved.

To assess the degree of innovation, a literature survey was performed, together with an analysis of the program for innovation in agriculture within the current development of the The agricultural European Innovation Partnership (EIP-AGRI) program for innovation and their application to a real case. Special attention was given to the conflicts that may arise when the innovation was applied to 
other sectors of the economy, and applied in identical terms in agriculture. To this end, an analysis of agricultural policy was performed.

A descriptive analysis was carried out, describing the phenomenon within its context; this analysis is also explanatory, i.e., it intends to explain cause-and-effect relationships within a theory. We have tried, through a real case, to highlight the dichotomy between the concept and practice of innovation in agriculture so as to objectify the difficulties of disembodied innovation in agriculture.

This work is based on a real case study, called: "Case Study: The OG for water management improvement in Lis Valley Irrigation District, Portugal".

To perform the analysis, we got hold of the available information from the following sources: The National Institute of Statistics (INE), European Network for Rural Development, and the National Reports of Rural Portuguese Program and the outputs from Portuguese Rural Development.

\section{Results and Discussion}

\subsection{Investment in Innovation}

Despite the importance of innovation, the expenditure on Research and Development has declined, with the exception of medical sciences and humanities. The area of engineering and technology represents the largest area of investment, and agrarian sciences accounted for about 3\% of the investment. Despite its importance in Portugal, investment fell during the analyzed period (Table 2). In Table 2 we can observe the Growth Rate (GR) and the Annual Growth Rate (average for three years, 2008-2010 and 2014-2016). Those values show a decrease in expenditure on R\&D, as referred to previously.

Table 2. Gross domestic expenditure on Research and Development (R\&D) by the field in M€, and in percentages (\%) of the total expenditure of the Portuguese economy.

\begin{tabular}{|c|c|c|c|c|c|c|c|c|c|c|c|c|c|c|c|c|c|c|c|c|c|}
\hline \multirow[b]{3}{*}{ Total } & \multicolumn{2}{|c|}{2008} & \multicolumn{2}{|c|}{2009} & \multicolumn{2}{|c|}{2010} & \multicolumn{2}{|c|}{2011} & \multicolumn{2}{|c|}{2012} & \multicolumn{2}{|c|}{2013} & \multicolumn{2}{|c|}{2014} & \multicolumn{2}{|c|}{2015} & \multicolumn{2}{|c|}{2016 * } & \multirow{2}{*}{\multicolumn{2}{|c|}{$\begin{array}{c}\text { 2008-2016 } \\
\text { AGR (\%) }\end{array}$}} & \multirow{3}{*}{$\begin{array}{c}2008-10 / \\
2014-16 \\
\text { AGR (\%) } \\
-2.8\end{array}$} \\
\hline & \multirow{2}{*}{$\frac{\text { M€ }}{2585}$} & \multirow{2}{*}{$\begin{array}{l}\% \\
100\end{array}$} & \multirow{2}{*}{$\begin{array}{l}\text { M€ } \\
2772\end{array}$} & \multirow{2}{*}{$\begin{array}{l}\% \\
100\end{array}$} & \multirow{2}{*}{$\begin{array}{l}\text { M€ } \\
2758\end{array}$} & \multirow{2}{*}{$\begin{array}{c}\% \\
100\end{array}$} & \multirow{2}{*}{$\begin{array}{l}\text { M€ } \\
2566\end{array}$} & \multirow{2}{*}{$\frac{\%}{100}$} & \multirow{2}{*}{$\begin{array}{l}\text { M€ } \\
2320\end{array}$} & \multirow{2}{*}{$\begin{array}{c}\% \\
100\end{array}$} & \multirow{2}{*}{$\frac{\text { M€ }}{2258}$} & \multirow{2}{*}{$\frac{\%}{100}$} & \multirow{2}{*}{$\begin{array}{l}\text { M€ } \\
2232\end{array}$} & \multirow{2}{*}{$\begin{array}{c}\% \\
100\end{array}$} & \multirow{2}{*}{$\frac{\text { M€ }}{2234}$} & \multirow{2}{*}{$\begin{array}{l}\% \\
100\end{array}$} & \multirow{2}{*}{$\frac{\text { M€ }}{2388}$} & \multirow{2}{*}{$\begin{array}{l}\% \\
100\end{array}$} & & & \\
\hline & & & & & & & & & & & & & & & & & & & -7.6 & -1.0 & \\
\hline $\begin{array}{l}\text { Natural } \\
\text { sciences } \\
\text { and } \\
\text { engineering }\end{array}$ & 2166 & 84 & 2275 & 82 & 2246 & 81 & 2113 & 82 & 1931 & 101 & 1838 & 81 & 1818 & $81 \%$ & 1813 & 81 & 1580 & 66 & -27.0 & -3.9 & -8.2 \\
\hline $\begin{array}{l}\text { Natural } \\
\text { sciences }\end{array}$ & 773 & 30 & 674 & 24 & 719 & 26 & 565 & 27 & 534 & 100 & 541 & 24 & 562 & $25 \%$ & 541 & 24 & 198 & 8 & -74.4 & -15.7 & -8.1 \\
\hline $\begin{array}{l}\text { Engineering } \\
\text { and } \\
\text { technology }\end{array}$ & 1027 & 40 & 1204 & 43 & 1118 & 41 & 1115 & 197 & 1000 & 100 & 939 & 42 & 892 & $40 \%$ & 910 & 41 & 1018 & 43 & -0.9 & -0.1 & -2.8 \\
\hline $\begin{array}{l}\text { Medical } \\
\text { and health } \\
\text { sciences }\end{array}$ & 278 & 11 & 290 & 10 & 311 & 11 & 327 & 29 & 301 & 100 & 277 & 12 & 284 & $13 \%$ & 288 & 13 & 290 & 12 & 4.0 & 0.5 & -0.4 \\
\hline $\begin{array}{l}\text { Agricultural } \\
\text { and } \\
\text { veterinary } \\
\text { sciences }\end{array}$ & 87 & 3 & 107 & 4 & 98 & 4 & 105 & 32 & 96 & 100 & 81 & 4 & 80 & $4 \%$ & 74 & 3 & 74 & 3 & -14.5 & -1.9 & -4.0 \\
\hline $\begin{array}{c}\text { Social } \\
\text { sciences, } \\
\text { humanities, } \\
\text { and arts }\end{array}$ & 420 & 16 & 496 & 18 & 512 & 19 & 454 & 430 & 389 & 100 & 420 & 19 & 415 & $19 \%$ & 421 & 19 & 441 & 18 & 5.2 & 0.6 & -1.8 \\
\hline $\begin{array}{c}\text { Social } \\
\text { sciences }\end{array}$ & 310 & 12 & 343 & 12 & 357 & 13 & 310 & 68 & 255 & 100 & 263 & 12 & 255 & $11 \%$ & 276 & 12 & 285 & 12 & -8.1 & -1.0 & -3.5 \\
\hline $\begin{array}{l}\text { Humanities } \\
\text { and arts }\end{array}$ & 109 & 4 & 153 & 6 & 155 & 6 & 144 & 47 & 134 & 100 & 157 & 7 & 159 & $7 \%$ & 145 & 6 & 156 & 7 & 43.1 & 4.6 & 1.7 \\
\hline
\end{tabular}

Source: Adapted from: OECD [25]; * Estatísticas de Investigação e Desenvolvimento [26], 14 May 2018.

During the period of 2009-2017, the Gross Value Added (GVA) of both agriculture and the Food and Beverage sector $(F \& B)$ remained constant at around $1 \%$ and $2 \%$ of the GVA of the total economy, respectively. The importance of the $F \& B$ sector is related to the weight on exports and on trade balance improvement. Between 2015-2017, exports from the agri-food industries, including Agriculture and F\&B products, represented circa $11 \%$ of total Portuguese goods exports with an Annual Growth Rate 
(AGR) of 6\% per year for the periods of 2009-2011 and 2015-2017. For these periods, the AGR of imports was around $2 \%$ per year, lower than the growth rate of exports.

Exports of agricultural products increased in importance when compared with the exports of Agri-Food Industries. Agricultural exports in 2017 represented 58\% of Agri-Food exports, and the Annual Growth Rate (AGR) of the agricultural sector was about $8 \%$ per year (tri-annual average), higher than both the AGR of the F\&B sector (3\%) and of the total economy (6\%). The export of agricultural products has increasingly acquired relevant importance, and this fact is relevant for the agricultural area, which is the core of this project.

\subsection{Rural Development Policy and Agricultural Innovation}

To promote R\&D and foster innovation, the EU has implemented the EPI-AGRI [6]. The EPI-AGRI is supported by the Rural Development Program 2014-2020 (RDP 2014-2020) and by Horizon 2020. The RDP 2014-2020 can be seen as a Focus Area (FA), and its policy comprises six priorities, associated to the Focus Area (Table 3).

Table 3. Priorities and focus area (FA) of the Rural Development Program (RDP), 2014-2020.

\begin{tabular}{|c|c|}
\hline Priorities & Focus Area \\
\hline $\begin{array}{l}\text { 1: Knowledge Transfer and } \\
\text { Innovation }\end{array}$ & $\begin{array}{l}\text { FA 1A: Fostering innovation, cooperation, and development of the } \\
\text { knowledge base in rural areas } \\
\text { FA 1B: Strengthening the links between agriculture, food production, } \\
\text { and forestry with research and innovation } \\
\text { FA 1C: Fostering lifelong learning and vocational training in the } \\
\text { agricultural and forestry sectors. }\end{array}$ \\
\hline $\begin{array}{l}\text { 2: Farm Viability and } \\
\text { Competitiveness }\end{array}$ & $\begin{array}{l}\text { FA 2A: Improving the economic performance of all farms and } \\
\text { facilitating farm restructuring and modernization } \\
\text { FA 2B: Facilitating the entry of adequately skilled farmers into the } \\
\text { agricultural sector and generational renewal. }\end{array}$ \\
\hline $\begin{array}{l}\text { 3: Food Chain Organization } \\
\text { and Risk Management }\end{array}$ & $\begin{array}{l}\text { FA 3A: Improving competitiveness of primary producers by } \\
\text { improving their integration into the agri-food chain } \\
\text { FA 3B: Supporting farm risk prevention and management }\end{array}$ \\
\hline $\begin{array}{l}\text { 4: Restoring, Preserving and } \\
\text { Enhancing Ecosystems }\end{array}$ & $\begin{array}{l}\text { FA 4A: Restoring, preserving, and enhancing biodiversity } \\
\text { FA 4B: Improving water management } \\
\text { FA 4C: Preventing soil erosion and improving soil management }\end{array}$ \\
\hline $\begin{array}{l}\text { 5: Resource-efficient } \\
\text { Climate-resilient Economy }\end{array}$ & $\begin{array}{l}\text { FA 5A: Increasing efficiency in water use by agriculture } \\
\text { FA 5B: Increasing efficient energy use in agriculture and food } \\
\text { processing } \\
\text { FA 5C: Facilitating the supply and use of renewable sources of energy } \\
\text { FA 5D: Reducing greenhouse gas and ammonia emissions from } \\
\text { agriculture } \\
\text { FA 5E: Fostering carbon conservation and sequestration in agriculture } \\
\text { and forestry }\end{array}$ \\
\hline $\begin{array}{l}\text { 6: Social Inclusion and } \\
\text { Economic Development }\end{array}$ & $\begin{array}{l}\text { FA 6A: Facilitating the diversification, creation, and development of } \\
\text { small enterprises, as well as job creation } \\
\text { FA 6B: Fostering local development in rural areas } \\
\text { FA 6C: Enhancing the accessibility, use, and quality of information and } \\
\text { communication technologies (ICT) in rural areas. }\end{array}$ \\
\hline
\end{tabular}

Priority 1 is included in Focus Area 1A, the FA for innovation, cooperation, and development of the knowledge base in rural areas. Within this FA there are three measures: M1, for knowledge transfer; M2, for advisory services; and M16, for cooperation.

According to EPI-AGRI [28], OGs "are intended to bring together multiple actors, such as farmers, researchers, advisers, businesses, environmental groups, consumer interest groups, or other NGOs, 
to advance innovation in the agricultural and forestry sectors", with the goal of promoting agricultural innovation to improve resource efficiency, productivity, climate-friendly solutions, and improve overall resilience. OGs are included under Measure 16 (M16) and its sub-measure 16.1 (M16.1). M16.1 provides financial support to create and manage OGs, to implement OG projects, and to disseminate knowledge produced by OGs. The majority of M16.1 projects deal with things like developing agricultural and forestry markets, the integration of supply chains, increasing product quality, and reinforcing the sectors witnessing expansion, such as organic farming.

Some projects focus on improving the competitiveness and productivity of farms in reaction to environmental challenges. OGs also include a social innovation dimension. The main difference between M16.1 and other measures in FA1 are the experimental proposals and the obligation to disseminate and transfer knowledge. In some countries, M16.1 measures are linked with other M16 actions and cooperation measures [29].

The most important criteria for project proposals is consistency with and contribution to objective 12 of the EIP-AGRI, which relates to the project's innovation potential to improve existing methods, techniques, and products; as well as objective 13, which relates to the project's feasibility, territorial relevance and expected territorial impact, the scope of the results, and importance of their impact. Figure 1 (country codes on Table 4) presents the expected number of cooperation actions supported by M16, and shows that Spain is the country with the highest number of targeted values.

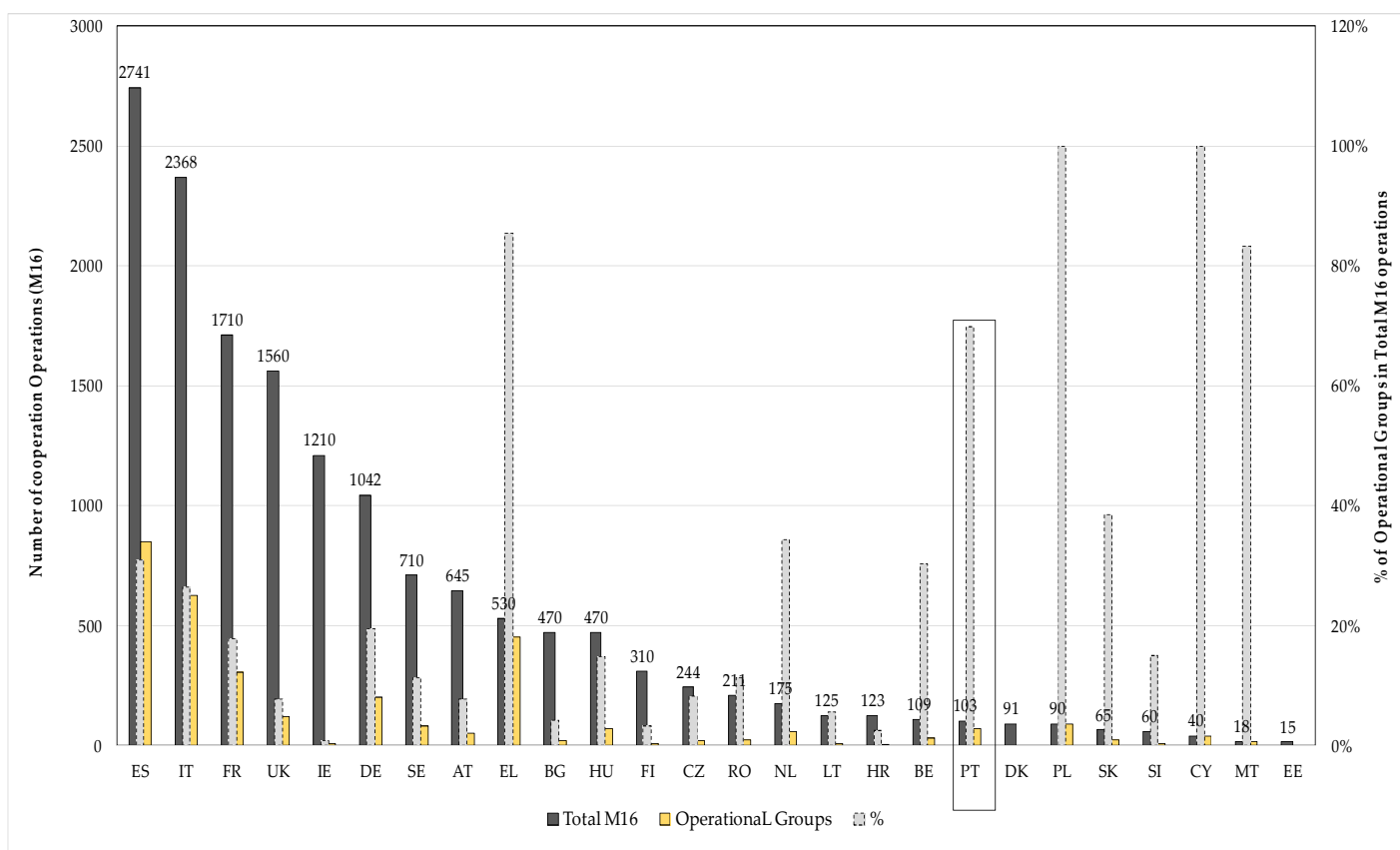

Figure 1. Expected number of cooperation actions supported under Measure 16 (M16), and percentage of Operational Groups (OGs) in total M16. Source: Adapted from RDP [30].

Table 4. European country codes applied on Figure 1 [30].

\begin{tabular}{cccccccc}
\hline Code & Country & Code & Country & Code & Country & Code & Country \\
\hline AT & Austria & EE & Estonia & IE & Ireland & PL & Poland \\
\hline BE & Belgium & EL & Greece & IT & Italy & PT & Portugal \\
\hline BG & Bulgaria & ES & Spain & LT & Lithuania & RO & Romania \\
\hline CY & Cyprus & FI & Finland & LU & Luxembourg & SE & Sweden \\
\hline CZ & Czech Republic & FR & France & LV & Latvia & SI & Slovenia \\
\hline DE & Germany & HR & Croatia & MT & Malta & SK & Slovakia \\
\hline DK & Denmark & HU & Hungary & NL & The Netherlands & UK & United Kingdom \\
\hline
\end{tabular}


In some countries, these measures are applied exclusively to OGs, which is the reason why the differences between countries are very significant. Four countries have $55 \%$ of the target number for M16 operations, and the same four countries had 59\% of the total targeted number of OGs. In terms of the target budget of RDP expenditure for the Focus Area 1A, it represents circa 3.9\% of RDP expenditures, which is about 156.5 billion euros (public and private). Figure 2 presents the expenditure for M1, M2, and M16, the percentage for this group under FA 1A, and the percentage for M16 where OGs are included. The results are very different for each country, and there is no link between the budget allocated for the FA 1A measure and the planned number of cooperation operations.

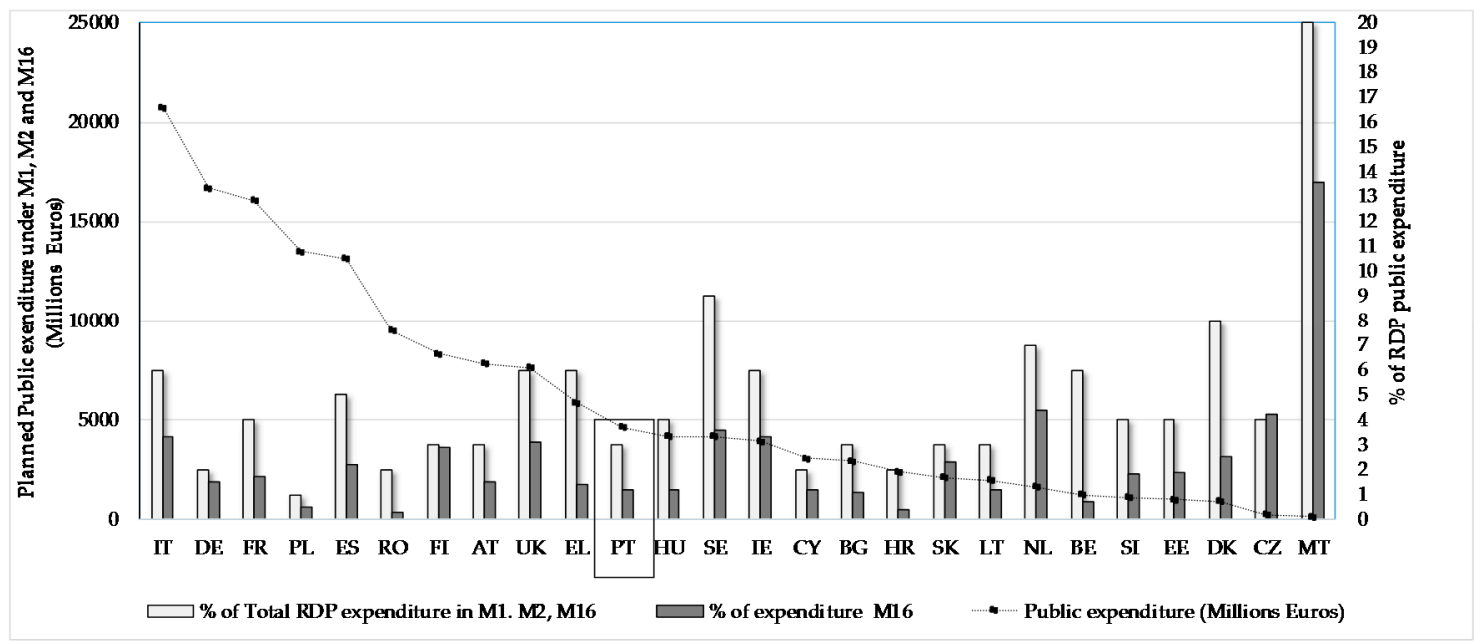

Figure 2. Target of RDP in expenditure under Measure: M1; M2 and M16 in value and percentage of RDP public expenditure. Source: Adapted from RDP [31].

\subsection{The Operational Groups in Portugal}

The European Agricultural Fund for Rural Development (EAFRD) created the OGs to fulfill the goals of EIP-AGRI. This was made in accordance with the regulation which stipulates that these groups are set up by stakeholders, including farmers, researchers, advisers, and companies in the agricultural, agri-food, and forestry sectors. In Portuguese mainland RDP, the OGs are included in FA A1-Measure 1 Innovation, sub-measure 1.1.

The Portuguese Rural Development Program (PDR2020) diagnosis showed that Portugal experiences difficulties in transmuting knowledge into innovation for the agricultural and forestry sectors, resulting in low sustainable growth, low efficiency, and poor protection of natural resources and biodiversity. Some of those barriers were identified-namely, the gap between knowledge produced and the producers' needs, the producers' limited access to the knowledge produced, the small size of farm structures, and the low qualification levels. The OGs' actions were targeted at achieving the objectives and priorities of rural development in the thematic areas considered by the sector as priorities for agricultural productivity and sustainability, with the aim of facilitating the creation of operational groups. To this end, meetings between those interested in developing innovation initiatives in the sector, as well as in avoiding the overlapping of action plans' objectives were promoted. In this context, the Initiatives Grant (IG) created in 2 October 2014 embodied the first phase of the OGs' proposal preparation, managed by the Rural National Network.

The budget of Portuguese RDP for Innovation and Knowledge (Action A1) was $2 \%$ of total public RDP expenditure, where a total of $95,053 \mathrm{M} €$ and $44 \%$ of the A1 budget was ascribed to OG in a total of $30.43 \mathrm{M} €$. The budget was allocated according to the priority shown in Table 5. 
Table 5. Allocation of budget according to priority, Action 1.1.

\begin{tabular}{lc}
\multicolumn{1}{c}{ Priority } & Budget (M€) \\
\hline $\begin{array}{l}\text { P2A. Improving the economic performance of farms through } \\
\text { restructuring and modernization, with the aim of improving market } \\
\text { orientation and diversification }\end{array}$ & 2000 \\
\hline $\begin{array}{l}\text { P3A. Increasing the competitiveness of farmers through better } \\
\text { integration of the agri-food supply chain, increased quality, added } \\
\text { value, and promotion in short circuits, and through integration on } \\
\text { producer organizations }\end{array}$ & 4304 \\
\hline $\begin{array}{l}\text { P4. Restoring and preserving agricultural and forest ecosystems } \\
\text { P5A. Increased water-use efficiency in agriculture }\end{array}$ & 8320 \\
\hline $\begin{array}{l}\text { P5B. Increased energy-use efficiency in the agri-food industry } \\
\text { P5C. Supply promotion of renewable energies and by-products to }\end{array}$ & 3328 \\
\hline $\begin{array}{l}\text { P5E. Promote bioeconomics } \\
\text { agroforestry sector }\end{array}$ & 2496 \\
\hline \begin{tabular}{l} 
P6B. Development of rural areas \\
\hline
\end{tabular} & 1664 \\
\hline
\end{tabular}

Source: Adapted from PDR2020 [32].

Four priorities are presented in Table 6. These priorities are related to the above-mentioned thematic domains, but as they do not coincide, it is hard to understand and include the domains in each priority.

Table 6. Thematic areas.

\begin{tabular}{ll}
\hline 1nd Priority & Increased resource efficiency in agricultural and forestry production \\
\hline 2nd Priority & Improved management of agricultural and forestry systems \\
\hline 2nd Priority & Improved market integration \\
\hline 4nd Priority & Valorization of territories \\
\hline & \multicolumn{2}{c}{ Source: Adapted from [33]. }
\end{tabular}

The criteria used to calculate the Global Value of Operation (GVO) and to select and rank the proposals was based on the following equation, where all the parameters were evaluated on a 0 to 20-point scale:

$$
\mathrm{GVO}=0.30 \mathrm{Q}+0.20 \mathrm{P}+0.30 \mathrm{~A}+0.10 \mathrm{~T}+0.10 \mathrm{~N}
$$

On Table 7 we can observe the grades according to each criterion.

Table 7. Grades (0-20 scale points) for each Global Value of Operation (GVO) variable.

\begin{tabular}{ccc}
\hline Parameters & Type of Criterion & Points \\
\hline N: Non-overlap with Other Operational Groups' initiatives & \\
\hline & no overlap & 20 \\
\hline & Overlap & 0 \\
\hline
\end{tabular}


Table 7. Cont.

\begin{tabular}{|c|c|c|}
\hline Parameters & Type of Criterion & Points \\
\hline \multicolumn{3}{|c|}{ T: Thematic of the plan } \\
\hline $\begin{array}{l}\text { Increased resource efficiency in } \\
\text { agricultural and forestry production }\end{array}$ & 1st priority & 20 \\
\hline $\begin{array}{l}\text { Improved management of agricultural } \\
\text { and forestry systems }\end{array}$ & 2st priority & 15 \\
\hline Improved market integration & 3st priority & 10 \\
\hline Valorization of territories & 4st priority & 5 \\
\hline \multicolumn{3}{|c|}{ A: Adequacy of the partnership to the action plan: } \\
\hline \multicolumn{3}{|c|}{$\mathbf{A}=0.30 \mathbf{A} 1+0.30 \mathbf{A} 2+0.30 \mathbf{A} 3+0.10 \mathbf{A} 4$} \\
\hline \multicolumn{3}{|c|}{ 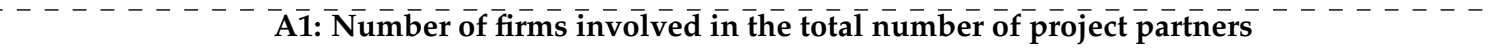 } \\
\hline & $>50 \%$ & 20 \\
\hline \multirow{3}{*}{\multicolumn{3}{|c|}{$\begin{array}{c}>33 \% \text { and } \leq 50 \% \\
\leq 33 \% \\
-D_{-}\end{array}$}} \\
\hline & & \\
\hline & & \\
\hline \multirow{3}{*}{\multicolumn{3}{|c|}{ 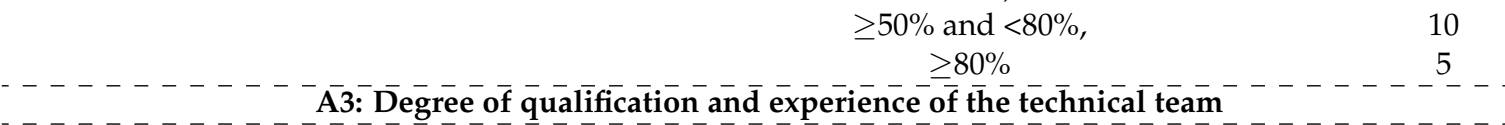 }} \\
\hline & & \\
\hline & & \\
\hline \multirow{5}{*}{$\begin{array}{l}\text { Percentage of human resources with } \\
\text { university degrees, and no. of } \\
\text { professional years }\end{array}$} & 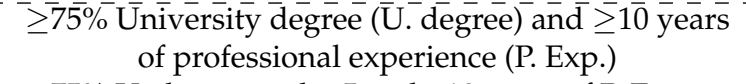 & 20 \\
\hline & $\begin{array}{l}\geq 75 \% \text { U. degree and } \geq 5 \text { and }<10 \text { years of P. Exp. or } \\
\geq 50 \% \text { U. degree and } \geq 10 \text { years of P. Exp. }\end{array}$ & \\
\hline & $\begin{array}{c}<50 \% \text { U. degree and } 75 \% \text { without U. degree and } \geq 5 \\
\text { years of P. Exp. }\end{array}$ & 15 \\
\hline & $\begin{array}{l}\geq 50 \% \text { U. degree and }<75 \% \text { without University } \\
\text { degree and } \geq 5 \text { years of P. Exp. }\end{array}$ & 10 \\
\hline \multirow{2}{*}{\multicolumn{2}{|c|}{ 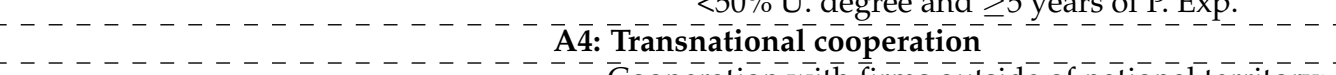 }} & 5 \\
\hline & & \\
\hline \multirow{2}{*}{ No. of cooperation with firms } & Cooperation with international research centers & 10 \\
\hline & $\begin{array}{l}\text { outside of national territory } \\
\text { No international cooperation }\end{array}$ & 0 \\
\hline \multicolumn{3}{|c|}{ P: Quality of the demonstration plan and dissemination of results } \\
\hline \multirow{4}{*}{$\begin{array}{l}\text { Web environment for the project results } \\
\text { Colloquiums or congresses } \\
\text { Focus groups } \\
\text { Technical publications }\end{array}$} & 4. Typologies & 20 \\
\hline & 3. Typologies & 15 \\
\hline & 2. Typologies & 10 \\
\hline & 1. Typologies & 5 \\
\hline \multicolumn{3}{|c|}{ Q: Quality of the action plan: } \\
\hline \multicolumn{3}{|c|}{$\mathbf{Q}=0.60 \mathbf{Q} 1+0.40 \mathbf{Q} 2$} \\
\hline \multicolumn{3}{|c|}{ Q1: Innovation factor } \\
\hline \multirow{4}{*}{$\begin{array}{l}\text { Product Innovation } \\
\text { Innovation process } \\
\text { Marketing Innovation }\end{array}$} & Prōuct and process innovation ${ }^{-}$ & $\overline{2} \overline{0}$ \\
\hline & Product and marketing innovation & 15 \\
\hline & Product or process or innovation & 10 \\
\hline & None of the above & 0 \\
\hline$-\cdots---\cdots-\cdots--\overline{\mathbf{Q}} \overline{2} \mathbf{Z}$ & ositioning in the Value Chain & \\
\hline & $\begin{array}{l}\text { Focus exclusively on primary production of } \overline{\text { po }}-\overline{-} \\
\text { agricultural or forestry products }\end{array}$ & -- \\
\hline $\begin{array}{l}\text { Attributed due to the importance of the } \\
\text { action plan in the value chain }\end{array}$ & $\begin{array}{l}\text { Focus partially on primary production of agricultural } \\
\text { or forestry products }\end{array}$ & 10 \\
\hline & $\begin{array}{l}\text { Focus on the first processing of agricultural or } \\
\text { forestry products }\end{array}$ & 5 \\
\hline & None of the above & 0 \\
\hline
\end{tabular}


The $\mathrm{Q}$ parameter refers to the quality of the action plan assessing the quality plan against the goals to be reached. The $Q$ parameter is the key problem and the core issue discussed in this work, related to the OG case study. The $Q$ parameter results from the application of Equation (3).

The different typologies defined by the RDP are identical to the OECD [21]-namely, the innovation product, i.e., the introduction of new products in the market; the innovation process, consisting of the implantation of a new or significantly improved production process; marketing innovation, through a new approach to the marketing mix in the supply of agricultural or forestry products, and to create differentiated positioning among consumers in previously identified markets.

The application of the $Q$ criterion, as well as the concept of innovation in agriculture, the link to thematic domains, and the priorities defined by Portuguese RDP, are complex. The OECD [34] mentions that agricultural innovation covers all research on the promotion of agriculture, forestry, fisheries, and foodstuffs, including research on the impact of agricultural and forestry activities on the environment, as well as research on the development of rural areas, improvement on agricultural water supply, and research on energy. This definition does not mention product innovation or process innovation, as defined by OECD and Eurostat [4-21] and by RDP to score project innovation in the Portuguese OG program (Q1 parameters).

This is an issue of many agricultural research proposals in which the innovation product, process, marketing, and even organizational aspects have to measure and evaluate in order to foster sustainable development.

This is particularly problematic because some advances in innovation cannot be assessed as they do not have a direct and prompt impact that can be evaluated in monetary or any other quantitative terms. In processes innovation, the impacts are generally felt in the medium- or long-term, making it difficult to evaluate their performance through the usual indicators of market and economic income. The consequent changes in organization or productive modes have environmental and socioeconomic implications that enhance the capacity for resilience and sustainability, making those innovations only measurable in a wider evaluative framework.

Some agricultural research is often not targeted at producing neither new products nor new processes. In what concerns agricultural and forestry products, sometimes it is difficult to identify what a new product or new process is. One fine example is research on organic farming and on the production of organic products. Therefore, it is of utmost relevance to define what is considered as new products and new processes.

The reintroduction of traditional varieties and their production can be considered as new products or new production processes, when the aim is to introduce as little changes as possible in the production system aiming at the maintenance of their autochthonous characteristics to satisfy a market niche.

Can we speak of a new marketing system or innovation in marketing, when what is proposed is the development a shorter supply food chain or a shorter circuit promoting direct sales from the producer to consumer, i.e., on the production site, appealing to traditional markets and to market proximity? Morgan and Murdoch [35] exploited knowledge and innovation in organic farming versus conventional agriculture, and set the distinction at standardized or codified knowledge and tactic or local knowledge: "which emerges in a rather unplanned and unforeseeable fashion, as bounded actors evolve ways of doing things in local situations which are context-dependent". The same authors emphasize the fact that "the conventional production process has moved into crisis, [resulting in] the fragility of farmers ..." "; however, one important piece of this fragility is their reliance and ability to explore new agricultural practices through applying old knowledge, which is sometimes an old memory reborn out of need and which ultimately becomes innovation.

For Terziev and Arabska [36], innovation is crucial to mitigating the effects of climate change and improving the competitiveness and sustainability of agricultural ecosystems. This RDP measure also includes innovation and knowledge, and the innovation concept includes relevant questions related to the classification and evaluation of OG case studies. 
These questions were also asked to other OG projects, whether the concept of innovation was understood as something new or producing something new, even if the meaning of "new" is highly subjective.

According to the data of PDR 2014-2020, 106 OGs out of 803 partnerships with signed contracts were approved. These OGs differ in both subject and object. Table 8 presents the results of the contest that began with the registration of groups in the OG. The level of support to be granted was $75 \%$ of the total eligible expenditure and a maximum support amount of 0,350 M€ per OG. The duration of the OG work plan execution ranged between 3 and 5 years. The delay in the approval and signing of contracts, in accordance with data in the RDP database, means that $54 \%$ of groups will finish the project in 2021, only 4 years after the project, although the time-frame set for the candidature of those $53 \%$ groups was 5 years. The delay in the evaluation process of applications may lead to critical issues in meeting the objectives, as well as to issues with the financial context in relation to the staff and the institutions themselves if the deadline is not extended.

\subsection{Case Study: The OG for Water Management Improvement in the Lis Valley Irrigation District, Portugal}

Portuguese agriculture is strongly influenced by its Mediterranean climate, implying that drainage and irrigation are techniques of utmost significance for soil conservation and land productivity. The high rainfall temporal variability, associated with frequent droughts, makes rainfed crop production very poor. In addition, crops with higher market prices, like fruit and vegetables, require irrigation to grow during summer's dry season. For this reason, nowadays, most economically feasible crops are irrigated. Also, considering the positive impacts of irrigation to mitigate the effects of expected climate changes that are expected to increase rainfall vagaries, the length of drought periods, and water scarcity, the Portuguese PDR gives a higher priority to the improvement of irrigation systems, with the development and rehabilitation of irrigation infrastructures to reduce water losses, improve management, and foster agricultural competitiveness.

The LVID is located in the Portuguese Center region, is $2000 \mathrm{ha}$, and is a public irrigation district with hydraulic infrastructures dating back from 1957. It is managed by the Water Users' Association (WUA). The main crops are forage corn, forage grass, horticultural, orchards and rice. Water is supplied by an open-channel conveyance network from weirs installed along the Lis river and tributaries, and by pumping from drainage ditches [38].

The OG (OGLIS) aims to improve water management in the Lis Valley Irrigation District (LVID). The partners are two research teams from the Polytechnic Institute of Coimbra, as well as from the University of Coimbra, the Lis Valley Water Users Association, the Regional Board of the Center Region of the Ministry of Agriculture, three farmers' companies, and a group linked with the AKIS systems. The objectives of OGLIS are to enhance competitiveness and environmental quality through monitoring and experimental actions [39].

These objectives are to be achieved through an innovation approach based on the improvement of management processes, following up several advances of knowledge and practices quantified by several indicators related with water-pumping energy efficiency, off- and on-farm irrigation and drainage, water quality, operational water demand and distribution plans, and their economic assessment. The experimental procedure focuses on the soil and water management system in individual farmer fields, creating a dynamic knowledge extension with LVID farmers. 
Table 8. PDR2020 indicators on 2014-2020 period (by Areas of Intervention: Innovation and Knowledge and Operational Groups).

\begin{tabular}{|c|c|c|c|c|c|c|c|c|c|c|c|c|c|c|c|c|c|c|c|c|}
\hline \multirow[t]{2}{*}{ Operations } & \multicolumn{3}{|c|}{$\begin{array}{l}\text { Public Expenditure } \\
\text { Allocated }\end{array}$} & \multicolumn{2}{|c|}{$\begin{array}{l}\text { Application } \\
\text { Submitted }\end{array}$} & \multicolumn{3}{|c|}{ Applications Review } & \multicolumn{3}{|c|}{ Applications Approved } & \multicolumn{2}{|c|}{$\begin{array}{l}\text { Applications Not } \\
\text { Approved }\end{array}$} & \multicolumn{3}{|c|}{ Contracts } & \multicolumn{3}{|c|}{$\begin{array}{l}\text { Rate of Contracts in } \\
\text { Total Applications } \\
\text { Review }\end{array}$} & \multirow{2}{*}{$\begin{array}{c}\text { Total } \\
\text { Invest./ } \\
\text { Public Exp. }\end{array}$} \\
\hline & Total & Carry & Progr. & No. & Invest & No. & Invest & $\begin{array}{l}\text { Public } \\
\text { Exp. }\end{array}$ & No. & Invest & $\begin{array}{l}\text { Public } \\
\text { Exp. }\end{array}$ & No. & Invest. & No. & Invest. & $\begin{array}{l}\text { Public } \\
\text { Exp. }\end{array}$ & No. & Invest & $\begin{array}{l}\text { Public } \\
\text { Exp. }\end{array}$ & \\
\hline Fields & & $\mathrm{M} €$ & & No. & $\mathrm{M} €$ & No. & $\mathrm{M} €$ & $\mathrm{M} €$ & No. & $\mathrm{M} €$ & $\mathrm{M} €$ & No. & $\mathrm{M} €$ & No. & $\mathrm{M} €$ & $\mathrm{M} €$ & & $\%$ & & $\%$ \\
\hline $\begin{array}{c}\text { RDP } \\
2014-2020\end{array}$ & 4178.9 & 685.6 & 2887.7 & 44,696 & 6821.2 & 43,153 & 6861.9 & 2060.0 & 18,804 & 2869.0 & 1366.2 & 7903 & 1095.8 & 17,805 & 2046.9 & 1280.0 & 41 & 30 & 62 & 31 \\
\hline $\begin{array}{c}\text { A1. } \\
\text { Innovation } \\
\text { and } \\
\text { knowledge }\end{array}$ & 95.1 & 13.0 & 60.9 & 1883 & 147.6 & 1878 & 145.0 & 82.7 & 1087 & 79.3 & 44.6 & 103 & 15.9 & 949 & 52.8 & 39.9 & 51 & 36 & 48 & 42 \\
\hline $\begin{array}{l}\text { 1.0.1. } \\
\text { Operational } \\
\text { Groups }\end{array}$ & 42.1 & 11.5 & 30.4 & 1471 & 74.9 & 1470 & 74.7 & 49.1 & 912 & 46.6 & 29.2 & 2 & 0.0 & 809 & 34.4 & 25.8 & 55 & 46 & 53 & 61 \\
\hline $\begin{array}{c}(\%) \\
\text { Innovation/ } \\
\text { RDP }\end{array}$ & 2 & 2 & 2 & 4 & 2 & 4 & 2 & 1 & 6 & 3 & 3 & 1 & 1 & 5 & 3 & 3 & & & & \\
\hline $\begin{array}{c}(\%) \\
\text { OG/Innovtion }\end{array}$ & 44 & 88 & 50 & 78 & 51 & 78 & 51 & 59 & 84 & 59 & 65 & 2 & 0 & 85 & 65 & 65 & & & & \\
\hline
\end{tabular}


The project recipients include WUA, farmers, and private companies generating economic income, whose activity is expected to be boosted with the best use of water and soil and innovative technologies. Consumers are also recipients, since they will benefit from it in terms of food safety and product quality, as well as companies of agricultural factors, processing, and commercialization, that will benefit from the improvements in economic and productivity. This project, carried out in synchrony with the national irrigation plan, allows for the leverage of project results and provides WUA with technical and scientific knowledge and decision tools. It will pinpoint the best choices in what concerns project modernization, optimizing the opportunities to increase agriculture competitiveness. This is regarded as an important factor to increase exports and for the creation of wealth. Additionally, it is an important vector of rural development. Irrigation is a basic component of modern agriculture, and is a great help towards obtaining higher income levels that could support its sustainability, and it contributes to keep populations in rural areas, mitigating environmental risks such as forest fires, soil degradation, and biodiversity loss.

The Programs of OG [28] propose to assemble together all the actors of agri-food systems, promoting agricultural innovation through the development of new products, practices, processes and technologies, testing and adapting existing technologies and processes by applying the innovation concepts discussed above. When the initiative proposal of the OG for water management on LVID (OGLIS) was submitted, the first PDR evaluation said that the initiative plan did not have enough innovation because the goal was to implement a water management model on an existing system, based on monitoring and experiments, and applying methods that already existed in the market. Supported by these arguments, the evaluation panel considered that the project did not fit the innovation criteria and, therefore, that it could not participate in that measure.

Innovations may be classified as embodied and disembodied. New innovations emerge in response to real problems and economic opportunities [40]. Public organizations have an important role in the development of disembodied innovations, because they do not refer to new products or tools, but rather to new management procedures that will change a system's behavior and performance. In fact, innovation is defined as the act of modifying and/or changing habits in the pursuit of continuous improvement, of products, services, or management types. This is undoubtedly a proposal that links research to practical application, embodying the dichotomy: "Research versus Application".

OGLIS is beyond the concept of disembodied innovation, while RDP is frequently applied in general to the concept of embodied innovation. OGLIS argues that the innovation proposal referred to a "new process" of LVID water management based on research activity, environmental monitoring, field experimentation, and demonstration to the beneficiaries, with the results being expected to be extrapolated to the overall irrigation district, supporting its modernization.

Some agricultural innovations have difficulty in being considered as innovations under a more classic definition. According to the Innovation Factor criterion (Q1), OGLIS has a null punctuation, because it is said that the proposed action plan does not lead to the innovation of a new product, process, or technology. According to research on several indicators mentioned above, it doesn't lead to innovation of a product, process or technology, since the final products do not fit the List on Annex I [41] concerning the Treaty on the Functioning of the European Union, that only refers to "products" in the strict sense of plant or animal species. In fact, as far as the new process is concerned, there is no sign of change in the agronomic model of crops that might benefit from the platform. Generally speaking, there is a concern to optimize the irrigated agriculture of the Lis Valley project.

However, as established by the governing Administrative Rule no. 402/2015 of November 9th 2015, new dimensions of the T parameter (concerning the different priorities of OG programs and used to evaluate proposals) are considered. The first priority is linked with increasing the efficiency of resources in agricultural and forestry production, and sub-priority 1.2 [33] highlights improving water use efficiency and its quality through the rational use of production factors (e.g., fertilizers, pesticides, effluents). 
These priorities refer to improved production practices, including changes in technology directly related to agricultural production. This is the basis of action which does not mention the production of new products. Requesting different rules about the product or process innovation is an important issue and the subjective view of innovation emphasizes the need to develop the concept of both innovation and priorities within the EU. This is central to the potential impact of innovation on economic performance and income.

OGLIS argued that its plan of action aims at innovation at several levels, exploiting the multi-functionality of irrigated agriculture. "Process innovation", through the implementation of improved production practices-including changes in technology—is directly related to the production of agricultural products. Concomitantly, "marketing innovation", through actions taken to improve market opportunity involving participatory processes between farmers and other stakeholders, are fundamental innovations with major impacts on overall performance and income, although they are not related to new products or processes. In turn, it promotes the supply of agricultural products to foster a differentiated position in the market, and involves the full supply chain, presenting a wider and more open approach to "product innovation", resulting from changes brought about by the implementation of improved production practices, with higher added-value products for the benefit of agricultural undertakings. There is also a need to consider social innovation that focus on participatory meetings, and that introduce and enhance farmers' involvement in social life and the environment [41].

OGLIS is focused on various advances in knowledge, directed in a concerted and pragmatic manner to WUA management of LVID, the field management of water and soil by farmers, and the creation of knowledge dynamics in farmers' associations. Practical utility is the most relevant of its merits, with a strategic vision of bringing knowledge to concrete implementation, for which there are no standard recipes available in the market.

The scope of research, experimentation, and tasks are focused on innovation, and are evident in the various methodological components of the proposal, such as: Ecotoxicological risk assessment and experimentation of mitigation measures by the farmer; irrigation operation warnings based on observations and local parametrization; testing and field evaluation on new irrigation and drainage technologies and their interrelation with the collective hydraulic network; remote sensing cultural mapping and its application to irrigation and drainage management; economic analysis to assess the viability of technologies and acceptance by farmers.

It should be recognized that monitoring actions are strategically targeted towards the building of a knowledge database, an essential requirement for rational management and the ultimate aim to its continuous use and applicability in the future, with possible integration into the management system at the LVID. After all this discussion about innovation, the score remained zero, though the OGLIS was approved based on the GVO score.

\section{Conclusions}

Innovation in agriculture outreaches the traditional innovation framework common for other activity areas, in the sense that improvement, competitiveness, enhanced production, and value can steam from dynamics other than new products or new production processes.

Portugal provides a fine example of how a simplistic, underdeveloped, and over-simplistic formulation of the innovation concept and consequent assessment criteria can hamper the impact of measures set to foster innovation in the agriculture sector. This, due to its complexity, it has to embrace intangible dimensions and processes, and is difficult to measure but of paramount importance to adding value and competitiveness to the productive strands. These cannot be considered as new products or new processes (sometimes it is quite the opposite, when the aim is to preserve ancillary products or production processes that acquire an improved added value due to their integrity and proven superior quality). 
This paper has shown that RDP OGs innovation priorities are restricted when a product-making process or marketing is not aligned with the OG goal of innovation. We suggest the applied RDP selection criteria for innovation systems should be adjusted to the OEDC definition and be upgraded, including regarding the knowledge and education areas of business and enterprise fields, and to bridge institutions linking the two [42].

Much research and innovation has emphasized technical innovation; however, it may be much more important to understand institutional innovations [43,44]. Agricultural economic literature on innovation highlights that innovations do not occur arbitrarily, and that incentives and institutional policies affect the nature and rate of innovation and adoption [38]. One of the challenges of technology policy schemes in agriculture is to obtain an optimal mix of public and private efforts to maximize impact. Producing new products or processes may be of interest to the private sector, but if innovation does not promote increased productivity or profitability, it is still relevant to society in regard to aiming at increasing sustainability in systems. Although this type of innovation is not so interesting to the private sector as it is to the public sector, it plays an important role as the developer and promoter of non-tangible innovation.

Sustainability is not only about the most effective use of natural resources, but it is also about developing and sustaining human resources in a region. It is famously difficult to measure and create sustainability in short-term processes. The RDP priority, defined in Action 1.01, considers innovation efforts to increase the efficiency of natural resource use on rural development. Measuring the results of disembodied innovation or evaluating the results of a new organizational process in agriculture is complex and not valuable in a short time period.

System changes aiming at more sustainable agriculture take longer to be evaluated, since they need new and innovative procedures and practices to create more resilient and well-adapted systems. Designing policies for innovation in agriculture will need improved understanding of these complex innovation learning and adaptation processes at several institutional and technological scenarios. The difficulty in understanding and integrating the theory of applied innovation in other economic sectors versus agricultural sustainability innovation may be one of the explanations for the certain under-performance of Portuguese agriculture. These issues will be difficult to overcome if decision-makers do not optimize the synergistic use of resources, with the goal of seizing implementation in the near future, as well as the innovation and consolidated scientific knowledge yet to be developed.

Assuming the complexity of the definition of "innovation" applied widely to agricultural systems, RDPs should review their concepts and rules to provide more efficient support to innovative actions aiming to enhance rural development. Efforts should be made by defining what "innovative" is, as well as its related activities that deserve financial support to improve public investment profitability [45].

Author Contributions: M.d.F.O. conceptualize and design the study; M.d.F.O., F.G.d.S. and J.M.G. conceived the methodology; S.F., M.T. and H.D. performed the data curation; M.d.F.O., A.D.F. and J.M.G. writing-review and editing.

Funding: This research was conducted within project Grupo Operacional para a Gestão da Água no Vale do Lis, PDR2020-1.0.1-FEADER-030911, funded by Program PDR2020, co-funded by FEDER, Innovation Measure, Portugal, and by Research Centre for Natural Resources, Environment and Society-CERNAS — under project UID/AMB/00681/2013 Funded by the Portuguese Science and Technology Foundation (FCT).

Acknowledgments: The authors wish to thank to Ana Bela Lopes, for her improvement of the manuscript level of English. Affiliation: Instituto Politécnico de Coimbra, Escola Superior Agrária, 3045-601 Coimbra, Portugal.

Conflicts of Interest: The authors declare no conflict of interest. 


\section{References}

1. Pigford, A.-A.E.; Hickey, G.M.; Klerkx, L. Beyond agricultural innovation systems? Exploring an agricultural innovation ecosystems approach for niche design and development in sustainability transitions. Agric. Syst. 2018, 164, 116-121. [CrossRef]

2. European Union, “Investigação e inovação". Compreender as Políticas da União Europeia: Investigação e Inovação; European Union: Brussels, Belgium, 2018; Available online: https:/ / europa.eu/european-union/topics / research-innovation_pt (accessed on 12 June 2018).

3. Ferreira, A.; Guilherme, R.; Ferreira, C.; Oliveira, M. Urban Agriculture, a tool towards more resilient urban communities? Curr. Opin. Environ. Sci. Health 2018, 5, 93-97. [CrossRef]

4. OECD/Eurostat. Oslo Manual: Guidelines for Collecting and Interpreting Innovation Data, 3rd ed.; The Measurement of Scientific and Technological Activities; OECD Publishing: Paris, France, 2005. [CrossRef]

5. OECD. Innovation Strategy: Defining Innovation. 2018. Available online: www.oecd.org/site/ innovationstrategy/defininginnovation.htm (accessed on 4 April 2018).

6. Labarthe, P.; Laurent, C.; Andriew, T.; Mora, A.; Caggiano, M. Prospects for Farmers' Support: Advisory Services in European AKIS WP 2-Advisory Services within AKIS: International Debates". Deliverable 2.2 Systematic Reviews of Academic Literature for Evaluating the Effectiveness of Farm Advisory Services Preliminary Findings Based on a Case Study about Farm Advice and Occupational Health; PROAKIS: National Research for Agricultural Research (INRA), Research department "Sciences for Action and Development (SAD): Paris, France, 4 December 2014.

7. European Commission. Guidelines on Programming for Innovation and the Implementation of the EPI for Agricultural and Sustainability; EIP-AGRI Document; European Commission Directorate-General for Agriculture and Rural Development: Brussels, Belgium, 2014.

8. Labarthe, P.; Caggiano, M.; Laurent, C.; Faure, G.; Cerf, M. Prospects for Farmers' Support: Advisory Services in European AKIS (PRO-AKIS): WP2-Advisory Services within AKIS: International Debates. Deliverable WP.2-1 Concepts and Theories Available to Describe the Functioning and Dynamics of Agricultural Advisory Services; PROAKIS: Paris, France, 2013; Available online: http:/ / proakis.webarchive.hutton.ac.uk/files/Deliverable_ WP2\%201_concepts\%20and\%20theories\%20of\%20AKIS(1).pdf (accessed on 4 April 2018).

9. Rajalahti, R.; Willem, J.; Eija, P. Agricultural Innovation Systems: From Diagnostics Toward Operational Practices; Agriculture and Rural Development Discussion Paper 38; Agriculture \& Rural Development Department; World Bank: Washington, DC, USA, 2008.

10. Leeuwis, C. Development and Support Role of Extension Services for Sustainable Intensification in Agriculture: Moving from Extension to Innovation Intermediation. In Proceedings of the Teagasc Best Practice in Extension Services 'Supporting Farmer Innovation, Dublin, Ireland, 1 November 2012.

11. World Bank. Agricultural Innovation Systems: An Investment Sourcebook; Agricultural and Rural Development. World Bank; World Bank Publications: Washington, DC, USA, 2012; 680p.

12. Sandoval, R. Investigación Sobre los Factores Determinants de la Innovación y el Uso de Servicios Intensivos en Conocimento en la Produción Agraria. Ph.D. Thesis, Universitat Politécnica de Valência, Valência, Spain, December 2017.

13. Prager, K.; Creaney, R.; Lorenzo-Arribas, A. Criteria for a system level evaluation of farm advisory services. Land Use Policy 2017, 61, 86-98. [CrossRef]

14. Knierim, A.; Prager, K.; Hutton, J. Agricultural Knowledge and Information Systems in Europe: Weak or Strong, Fragmented or Integrated? PRO AKIS, European Commission 7th Framework Programme Project; PROAKIS: Paris, France, 2015; Available online: http:/ / proakis.webarchive.hutton.ac.uk/sites/www.proakis.eu/files / AKIS_characterisation_briefing_final.pdf (accessed on 14 March 2018).

15. Rivera, W.; Qamar, M.; Mwandemere, H. Enchancing Coordination among AKIS/RD actors, An Analytical and Comparative Review of Country Studies on Agricultural Knowledge and Information Systems for Rural Development AKIS/RD, 2005. Research, Extension and Training Division Sustainable Development Department; FAO: Rome, Italy, 2005.

16. Dockès, A.C.; Tisenkopfs, T.; Bock, B. Collaborative Working Group Agricultural Knowledge and Innovation Systems; WP1: Reflection Paper on AKIS. Sub-Deliverable of the AKIS CWG-WP1; European Commission: Brussels, Belgium, April 2011.

17. Smits, R.E.; Kuhlmann, S.; Shapira, P. The Theory and Practice of Innovation Policy —An International Research Handbook; Edgar Elgar: Chaltenham, UK, 2010; 496p. 
18. EU-SCAR. Agricultural Knowledge and Innovation Systems Towards 2020-An Orientation Paper on Linking Innovation and Research; European Commission: Brussels, Belgium, 2013.

19. Edler, J.; Fagerberg, J. Innovation policy: What, why, and how. Oxf. Rev. Econ. Policy 2017, 33, 2-23. [CrossRef]

20. OECD. The Measurement of Scientific and Technical Activities: Standard Practice for Surveys of Research and Experimental Development_Frascati Manual 1993; The Measurement of Scientific and Technological Activities; OECD Publishing: Paris, France, 1994.

21. OECD. Agricultural Innovation Systems: A Framework for Analysing the Role of the Government; OECD Publishing: Paris, France, 2013.

22. Gault, F. Defining and Measuring Innovation in all Sectors of the Economy: Policy Relevance. In Proceedings of the OECD Blue Sky Forum III, Ghent, Belgium, 19-21 September 2016; pp. 19-21.

23. Gault, F. Defining and measuring innovation in all sectors of the economy. Res. Policy 2018, 47, 617-622. [CrossRef]

24. European Commission. Green Paper on Innovation, Bulletin of the European Union; European Commission: Luxembourg, 1996; Supplement 5/95.

25. OECD.Stat. Gross Domestic Expenditure on R\&D by Sector of Performance and Field of R\&D (FORD), Data extracted on 14 May 2018 12:29 UTC (GMT) from OECD.Stat. Available online: https:/ / stats.oecd.org/ index.aspx?DatasetCode=GERD_FORD (accessed on 12 May 2018).

26. Estatísticas de Investigação e Desenvolvimento (I\&D). Inquérito ao Potencial Científico e Tecnológico Nacional 2016, Sumários Estatísticos. IPCTN16. 2018. Available online: http:/ / www.dgeec.mec.pt/np4/ 206/ (accessed on 14 May 2018).

27. European Network for Rural Development. European Network for Rural Development (ENRD). 2018. Available online: https:/ / enrd.ec.europa.eu/policy-in-action/rural-development-policy-figures / priorityfocus-area-summaries_en (accessed on 17 July 2018).

28. EPI-AGRI. EIP-AGRI Operational Groups-Basic Principles. 2005. Available online: https:/ / ec.europa.eu/ eip/agriculture/en/eip-agri-operational-groups-\%E2\%80\%93-basic-principles (accessed on 20 May 2018).

29. RDP. Analysis: Measure 16 'Cooperation'M16.1, EIP, Operational Groups (s.d). Available online: https: / / enrd.ec.europa.eu/sites/enrd/files/rdp_analysis_m16-1.pdf (accessed on 16 March 2018).

30. RDP Rural Development Programmes 2014-2020: Key facts \& figures, FOCUS AREA 1B: Strengthening the links between agriculture, food production and forestry and research and innovation, (s.d). Available online: https:/ / enrd.ec.europa.eu/policy-in-action/rural-development-policy-figures/priority-focus-areasummaries_en (accessed on 18 April 2018).

31. RDP 2014-2020: Key Facts \& Figures FOCUS AREA 1A: Innovation, Cooperation, and Development of the Knowledge Base in Rural Areas (s.d). Available online: https: / /enrd.ec.europa.eu/sites/enrd/files/focusarea-summary_1a.pdf (accessed on 22 June 2018).

32. PDR2020 (2016), Anúncio de Abertura do Período de Apresentação de candidatura, No 01/Acção 1.1/2016, Grupos Operacionais, N. 01/Ação 1.1/2016. Available online: https:/ / enrd.ec.europa.eu/policy-in-action/ rural-development-policy-figures/priority-focus-area-summaries_en (accessed on 22 June 2018).

33. DR. Ministério da Agricultura e do Mar: Portaria n. ${ }^{\circ}$ 402/2015 de 9 de Novembro". Diário da República, 1 . $^{\mathrm{a}}$ série, N. ${ }^{\circ}$ 219, 9 de Novembro 2015. Available online: https:/ /www.portugal2020.pt/Portal2020/Media/ Default/Docs/Legislacao/RegEsp2020/Portaria402_2015.pdf (accessed on 22 June 2018).

34. OECD. Frascati Manual 2002: Proposed Standard Practice for Surveys on Research and Experimental Development; The Measurement of Scientific and Technological Activities; OECD Publishing: Paris, France, 2002. [CrossRef]

35. Morgan, K.; Murdoch, J. Organic. vs. conventional agriculture: Knowledge, power and innovation in the food chain. Geoforum 2000, 31, 159-173. [CrossRef]

36. Terziev, V.; Arabska, E. Enhancing Competitiveness and Sustainability of Agri-Food Sector through Market-Oriented Technology Development in Agricultural Knowledge and Innovation System in Bulgaria. In Proceedings of the III International Scientific Congress Agricultural Machinery, Varna, Bulgaria, 22-25 June 2015.

37. PDR2020 (2018), PDR2020 em Números: Indicadores de Monitorização PDR2020-30.06.2018. Available online: http:/ / www.pdr-2020.pt/site/PDR2020-em-numeros (accessed on 25 June 2018). 
38. Masseroni, D.; Ricart, S.; Cartagena, R.F.; Monserrat, J.; Gonçalves, J.M.; de Lima, I.; Facchi, A.; Sali, G.; Gandolfi, C. Prospects for Improving Gravity-Fed Surface Irrigation Systems in Mediterranean European Contexts. Water 2017, 9, 20. [CrossRef]

39. Gonçalves, J.M.; Damásio, H.; de Lima, I.; Castro, F.; Oliveira, F.; Teixeira, M.; Gonçalves, M.; Nunes, M.; Duarte, I.; Amador, P.; et al. Operational Group for water management in the Lis Valley: Improving the use of water and soil and agricultural competitiveness. In Proceedings of the VII National Congress of Irrigation and Drainage, Monte Real, Portugal, 27-29 June 2018. (In Portuguese)

40. Sunding, D.; Zilberman, D. The agricultural innovation process: Research and Technological adoption in a changing agriculture sector. In Book Handbook of Agricultural Economics; Bruce, L.G., Gordon, C.R., Eds.; Elsevier Science B.V.: Amsterdam, The Netherlands, 2001; Volume 1, Part A; pp. 207-226.

41. Jornal Oficial. Tratado da União Europeia e do Tratado sobre o Funcionamento da União Europeia; Jornal Oficial $n^{\circ} \mathrm{C}$ 326 de 26/10/2012; Jornal Oficial: da União Europeia, Lisboa, 2012; pp. 0001-0390.

42. EPI-AGR Operational Groups. 2015. Available online: https://ec.europa.eu/eip/agriculture/en/my-eipagri/operational-groups (accessed on 18 June 2018.).

43. Zilberman, D.; Heiman, A. The Value of Economic Research. Am. J. Agric. Econ. 1997, 79, 1539-1544. [CrossRef]

44. Spielman, D.; Birner, R. How Innovative Is Your Agriculture? Using Innovation Indicators and Benchmarks to Strengthen National Agricultural Innovation Systems. In Agriculture and Rural Development Discussion Paper, 2008, Nº; The International Bank for Reconstruction and Development World Bank: Washington, DC, USA, 2008.

45. EC. What Is Innovation? 2008. Available online: https://ec.europa.eu/eip/agriculture/en/whatiinnovation (accessed on 27 March 2018).

(C) 2019 by the authors. Licensee MDPI, Basel, Switzerland. This article is an open access article distributed under the terms and conditions of the Creative Commons Attribution (CC BY) license (http://creativecommons.org/licenses/by/4.0/). 